\title{
Mycorrhizal Distributions Impact Global Patterns of Carbon and Nutrient Cycling
}

\section{Journal Article}

\section{Author(s):}

Braghiere, Renato; Fisher, Joshua B.; Fisher, Rosie; Shi, Mingjie; Steidinger, Brian; Sulman, Benjamin N.; Soudzilovskaia, Nadejda; Yang, Xiaojuan; Liang, Jingjing; Peay, Kabir; Crowther, Thomas; Phillips, Richard P.

\section{Publication date:}

2021-10-16

\section{Permanent link:}

https://doi.org/10.3929/ethz-b-000510872

Rights / license:

Creative Commons Attribution 4.0 International

Originally published in:

Geophysical Research Letters 48(19), https://doi.org/10.1029/2021GL094514 


\section{Geophysical Research Letters ${ }^{\oplus}$}

\section{RESEARCH LETTER \\ 10.1029/2021GL094514}

Key Points:

- Uncertainties in mycorrhizal distributions are large with estimates disagreeing by up to $50 \%$ in $40 \%$ of the land area

- Global plant demand for nitrogen has increased $25 \%$ from 1850 to 2010 , while the carbon cost associated with it has increased $60 \%$ in the same period

- Areas of savannas and forestgrasslands transition zones present a higher risk of nitrogen limitation to plant growth

Supporting Information:

Supporting Information may be found in the online version of this article.

Correspondence to:

R. K. Braghiere and J. B. Fisher, renato.k.braghiere@jpl.nasa.gov; josh.fisher@gmail.com

\section{Citation:}

Braghiere, R. K., Fisher, J. B., Fisher, R. A., Shi, M., Steidinger, B. S., Sulman, B. N., et al. (2021). Mycorrhizal distributions impact global patterns of carbon and nutrient cycling. Geophysical Research Letters, 48, e2021GL094514. https://doi. org/10.1029/2021GL094514

Received 24 MAY 2021

Accepted 12 SEP 2021

\section{Author Contributions:}

Conceptualization: R. K. Braghiere, J. B. Fisher, R. P. Phillips

Formal analysis: R. K. Braghiere, J. B. Fisher, R. A. Fisher

Funding acquisition: J. B. Fisher,

X. Yang, J. Liang, K. G. Peay, T. W.

Crowther, R. P. Phillips

Investigation: R. K. Braghiere, J. B.

Fisher

Methodology: R. K. Braghiere, J. B. Fisher, R. A. Fisher, M. Shi, B. N. Sulman, N. A. Soudzilovskaia, X. Yang, R. P. Phillips

(c) 2021. The Authors.

This is an open access article under the terms of the Creative Commons Attribution License, which permits use, distribution and reproduction in any medium, provided the original work is properly cited.

\section{Mycorrhizal Distributions Impact Global Patterns of Carbon and Nutrient Cycling}

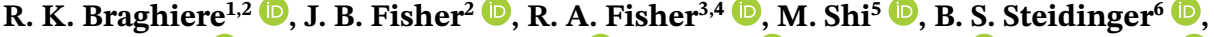 \\ B. N. Sulman ${ }^{7}$ (D) N. A. Soudzilovskaia ${ }^{8,9}$ (D) X. Yang6 ${ }^{6}$, J. Liang ${ }^{10,11}$ (D) K. G. Peay ${ }^{(1)}$, \\ T. W. Crowther' ${ }^{12}$, and R. P. Phillips ${ }^{13}$ (D)
}

\begin{abstract}
${ }^{1}$ Jet Propulsion Laboratory, California Institute of Technology, Pasadena, CA, USA, ${ }^{2}$ Joint Institute for Regional Earth System Science and Engineering, University of California at Los Angeles, Los Angeles, CA, USA, ${ }^{3}$ Climate and Global Dynamics Division, National Center for Atmospheric Research, Boulder, CO, USA, ${ }^{4}$ Laboratoire Évolution \& Diversité Biologique, CNRS:UMR, Université Paul Sabatier, Toulouse, France, ${ }^{5}$ Pacific Northwest National Laboratory, Richland, WA, USA, ${ }^{6}$ Department of Biology, Stanford University, Stanford, CA, USA, ${ }^{7}$ Environmental Sciences Division and Climate Change Science Institute, Oak Ridge National Laboratory, Oak Ridge, TN, USA, ${ }^{8}$ Department of Environmental Biology, Leiden University, Institute of Environmental Sciences, Leiden, The Netherlands, ${ }^{9}$ Centre for Environmental Sciences, Hasselt University, Hasselt, Belgium, ${ }^{10}$ Department of Forestry and Natural Resources, Purdue University, West Lafayette, IN, USA, ${ }^{11}$ Research Center of Forest Management Engineering of State Forestry and Grassland Administration, Beijing Forestry University, Beijing, China,

${ }^{12}$ Department of Environmental Systems Science, ETH Zürich, Zürich, Switzerland, ${ }^{13}$ Department of Biology, Indiana University, Bloomington, IN, USA
\end{abstract}

Abstract Most tree species predominantly associate with a single type of mycorrhizal fungi, which can differentially affect plant nutrient acquisition and biogeochemical cycling. Uncertainties in mycorrhizal distributions are non-trivial, and current estimates disagree in up to $50 \%$ over $40 \%$ of the land area, including tropical forests. Remote sensing capabilities for mycorrhizal detection show promise for refining these estimates further. Here, we address for the first time the impact of mycorrhizal distributions on global carbon and nutrient cycling. Using the state-of-the-art carbon-nitrogen economics within the Community Land Model version 5, we found Net Primary Productivity (NPP) increased throughout the 21st century by $20 \%$; however, as soil nitrogen has progressively become limiting, the costs to NPP for nitrogen acquisition - that is, to mycorrhizae-have increased at a faster rate by $60 \%$. This suggests that nutrient acquisition will increasingly demand a higher portion of assimilated carbon to support the same productivity.

Plain Language Summary Most plants join forces with specific types of fungi to improve their ability to acquire nutrients, which ultimately impact global photosynthesis. This is the first study to explore the impacts of different types of fungi-root distributions on global carbon and nutrient cycling. Current global estimates of fungi-root distributions do not agree in at least $40 \%$ of the land area. Using a global model, we found that global net carbon uptake increased throughout the 21 st century by $20 \%$, while the carbon spent on nitrogen acquisition increased at a faster rate by $60 \%$. This study suggests that nutrient acquisition by plants will increasingly demand a larger portion of net carbon to support the same photosynthesis.

\section{Introduction}

Terrestrial ecosystems have been a persistent post-industrial carbon sink, absorbing almost a third of anthropogenic carbon emissions (Ciais et al., 2013; Friedlingstein et al., 2020; Schimel et al., 2015). Studies suggest that terrestrial ecosystem productivity has increased due to elevated $\mathrm{CO}_{2}$ concentration $\left(\mathrm{eCO}_{2}\right.$; Chen et al., 2019; Keenan et al., 2016; Zhu et al., 2016), but it remains unclear whether this will translate to increases in the terrestrial carbon sink in the future (Friedlingstein et al., 2006, 2014; Schimel et al., 2015; Zhang et al., 2019). It is widely expected that limiting factors such as water (Kolus et al., 2019; Trenberth et al., 2014) and nutrients availability (Zaehle et al., 2010; Fleischer et al., 2019; Terrer et al., 2019; Walker et al., 2021; Wieder et al., 2015, 2019) might mediate the responses of terrestrial ecosystems to climate change. Disentangling these mechanisms and exploring the consequences of $\mathrm{eCO}_{2}$ require assessment of 
Supervision: J. B. Fisher, X. Yang Validation: R. K. Braghiere, M. Shi, B. S. Steidinger, B. N. Sulman, N. A. Soudzilovskaia, J. Liang, K. G. Peay, T. W. Crowther

Writing - original draft: R. K. Braghiere, J. B. Fisher Writing - review \& editing: R. K. Braghiere, J. B. Fisher, R. A. Fisher, M. Shi, B. S. Steidinger, B. N. Sulman, X. Yang, J. Liang, K. G. Peay, T. W. Crowther, R. P. Phillips such mechanisms through Earth System models (ESMs), which allow comprehensive and spatially explicit assessment of the impacts of future climate on biogeochemical cycles in terrestrial ecosystems.

A large part of plant nitrogen and phosphorus is provided by fungal root symbionts (van der Heijden et al., 2015); thus, it is likely that mycorrhizal associations explain a large fraction of the variance in plant response to $\mathrm{eCO}_{2}$ (Drake et al., 2011; Kivlin et al., 2013; Orwin et al., 2011; Sulman et al., 2017; Terrer et al., 2016, 2018, 2021). However, the global spatial distributions of these mechanisms as well as their potential impacts are still uncertain (Norby et al., 2017; Sulman et al., 2019). Only a handful of ESMs consider mycorrhizal nutrient acquisition when calculating carbon assimilation and allocation (Wang et al., 2010; Zaehle et al., 2015; Goll et al., 2017). The Community Land Model version 5 (CLM5) within the Community Earth System Model (CESM) currently enables an explicit representation of the functional differences between distinct types of plant symbiotic associations (Brzostek et al., 2014; J. B. Fisher et al., 2010; R. A. Fisher et al., 2019; Lawrence et al., 2019; Shi et al., 2016). However, until recently, one of the major challenges in generating global estimates of nutrient limitation on the global carbon cycle is related to a lack of information of the spatial distribution of nutrient-acquiring plant-microbe symbioses. Despite the availability of regional maps of present and past plant symbiotic status (Brundrett, 2017; Jo et al., 2019; Menzel et al., 2016; Swaty et al., 2016), scientists have only recently begun to develop explicit global data about mycorrhizal and nitrogen fixing associations (Davies-Barnard et al., 2020).

Recently, scientists developed methods for extrapolating spatially sparse measurements into large-scale maps suitable for applications within ESMs (Shi et al., 2016; Soudzilovskaia et al., 2019; Steidinger et al., 2019; Sulman et al., 2019). These developments for the first time enable examination of how mycorrhizal spatial distributions are related to global carbon and nitrogen cycles. In this study, we seek a better understanding of mycorrhizae on global carbon and nitrogen cycles through incorporation of multiple state-of-the-art spatial distributions of mycorrhizal associations in a global land surface model. We first compare four global maps of mycorrhizal associations. Second, we perform transient global runs of CLM5 with climate change, nitrogen deposition, land use change, and $\mathrm{eCO}_{2}$ through the 20th and 21st centuries in order to understand the impact of global changes associated with different spatially variable mycorrhizal representations. Finally, we evaluate possible feedback effects that spatial changes in mycorrhizal association due to climate change may have on the global carbon cycle in the future following a projected map presented in Steidinger et al. (2019).

\section{Materials and Methods}

\subsection{Land Surface Model Description: CLM5}

CLM5 includes the Fixation and Uptake of Nitrogen (FUN) module for calculating the carbon costs for each pathway of plant nitrogen uptake: symbiotic biological nitrogen fixation, non-mycorrhizal and mycorrhizal uptake of soil nitrogen, and nitrogen retranslocation from leaves (Allen et al., 2020; Brzostek et al., 2014; Fisher et al., 2010; Shi et al., 2016). Plants shift uptake pathways to minimize the carbon costs of nitrogen uptake. FUN simulates uptake from the two major types of fungi that plants associate with: arbuscular mycorrhizae (AM) and ectomycorrhizae (ECM) fungi.

To generate the trade-offs between AM, ECM, and non-mycorrhizal root uptake, FUN within CLM5 uses an estimate of the percentage of aboveground biomass per grid cell that associates with each mycorrhizal type (Brzostek et al., 2014; Shi et al., 2016). The carbon cost of nitrogen uptake $\left(\mathrm{N}_{\text {cost }}\right)$ from soil by mycorrhizae, for each soil layer $j$, is controlled by two uptake parameters $\left(k_{n \text {,pathway }}\right.$ and $\left.k_{c \text {,pathway }}\right)$ that pertain respectively to the relationship between soil nitrogen and nitrogen uptake, and between fine root carbon biomass and nitrogen uptake, given as:

$$
N_{\text {cost,pathway }, j}=\frac{k_{n, \text { pathway }}}{N_{s \min , j}}+\frac{k_{c, \text { pathway }}}{c_{\text {root }, j}}
$$

where $k_{n \text {,pathway }}\left(\mathrm{kgC} \mathrm{m}^{-2}\right)$ and $k_{c \text {,pathway }}\left(\mathrm{kgC} \mathrm{m}^{-2}\right)$ varies according to whether the pathway considered is referring to ECM or AM uptake. The uptake parameters were chosen so that the thresholds in nitrogen availability and root biomass mirror empirical shifts in the abundance of AM and ECM fungi and plants across fertility and latitudinal gradients as defined and calibrated by Brzostek et al. (2014). For ECM, $k_{n}=0.05 \mathrm{kgC} \mathrm{m}^{-2}$ and $k_{c}=0.3 \mathrm{kgC} \mathrm{m}^{-2}$; while for AM, $k_{n}=0.1 \mathrm{kgC} \mathrm{m}^{-2}$ and $k_{c}=0.05 \mathrm{kgC} \mathrm{m}^{-2} . N_{\text {smin,j }}$ and 
$c_{\text {root,j }}$ are the soil nitrogen content $\left(\mathrm{gN} \mathrm{m}^{-2}\right)$ and fine root carbon biomass $\left(\mathrm{gC} \mathrm{m}^{-2}\right)$, respectively (see Supporting Information S1 for details).

\subsection{Coupling Mycorrhizae Spatial Distribution Into CLM5}

Plant functional types (PFTs) are used to classify plants according to their physical, phylogenetic, and phenological characteristics. The parameters associated with each PFT is determined or inferred from observable characteristics of the land surface following different land types. A spatial data product can be added as a $2 \mathrm{D}$ variable varying as function of latitude and longitude, but because land surface models usually work with the concept of PFTs, adding a third spatial dimension (i.e., PFT) can represent within grid cell heterogeneity and improve accuracy of land surface processes, as well as reduce model uncertainty (Braghiere et al., 2019). Here, given new spatial distributions of mycorrhizal associations based on observations at different spatial resolutions, we modified CLM5 and added mycorrhizal association types per PFT within each gridcell. The total carbon cost of nitrogen uptake $\left(\mathrm{N}_{\text {cost }}\right)$ from soil by mycorrhizae is calculated as:

$$
N_{\text {cost,mycorrhizae }}=N_{\text {cost }, \mathrm{ECM}} \times \text { perECM }+N_{\text {cost,AM }} \times(1-\text { perECM })
$$

where perECM is the fraction of ECM association present in a PFT within a model grid cell.

Four global maps of mycorrhizal association based on different assumptions and spatial resolutions were used to provide the percentage of ECM association (relative to AM) for CLM5: Map A (default in CLM5; Shi et al., 2016); Map B (Sulman et al., 2019), Map C (Steidinger et al., 2019), and Map D (Soudzilovskaia et al., 2019) (see Figure 1 and Supporting Information S1 for details about each map). Map A presents binary ECM values per PFT with most of the tropics having 100\% AM and the boreal regions having $100 \%$ ECM. The other maps were derived from observations following different methodologies.

\subsection{Simulation Protocols}

First, for each ECM map, initial ecosystem carbon and nitrogen stocks for 1850 were generated using a spinup approach using 1850 concentrations of $\mathrm{CO}_{2}(284.7 \mathrm{ppm})$ and the model's standard climate forcing dataset from the Global Soil Wetness Project Phase 3 version 1 (GSWP3v1) (Kim, 2017) at $1.9^{\circ} \times 2.5^{\circ}$ spatial resolution. The Model for Scale Adaptive River Transport (MOSART) was turned on, and ice evolution on land was turned off. Model runs were performed with biogeochemistry mode on (without crops) for 200 years in “accelerated decomposition" mode (see Lawrence et al. (2019) for details) by cycling through the 1901-1920 climate forcing dataset, and for 400 years in regular spin-up mode until soil and plant carbon and nitrogen stocks achieved steady state. Historical simulations were performed from 1850 to 2010 using transient GSWP3 climate, nitrogen deposition, land-use change, and variable atmospheric $\mathrm{CO}_{2}$ concentration.

Second, in order to illustrate the model sensitivity to changes in global spatial patterns of plant symbiosis due to climate change, we used a projected map of plant symbiotic status for 2070 using a relative concentration pathway (RCP) of $8.5 \mathrm{~W} \mathrm{~m}^{-2}$ from Steidinger et al. (2019) versus the original map with present climate (Steidinger et al., 2019). We performed future runs (2015-2070) with the biogeochemistry mode on, following the Shared Socio-Economic Pathway (SSP) number 5 (Kriegler et al., 2017). SSP5 scenarios are the only ones resulting in a radiative forcing pathway as high as the highest RCP8.5 used by Steidinger et al. (2019). The SSP5 scenario includes extreme levels of fossil fuel use, up to a doubling of global food demand, and up to a tripling of energy demand and greenhouse gas emissions over the course of the century, marking the upper end of the scenario literature in several dimensions. We used future climatological forcing from the CESM2 simulation for the Coupled Model Intercomparison Project 6 (CMIP6; Eyring et al., 2016; Lawrence et al., 2016; O’Neill et al., 2016).

\subsection{Calculating Nitrogen Limitation}

The risk of nitrogen limitation (NL) can be determined by evaluating if the growth rate of NPP used for nitrogen uptake with time is larger than the growth rate of total NPP with time. If the amount of NPP used for nitrogen uptake increases at a higher rate than the total NPP for a particular grid cell, that grid cell is considered to be at risk of spending too much carbon on nitrogen acquisition, and therefore, NL is closer to 1 . On the contrary, if the amount of NPP used for nitrogen uptake increases at a lower rate than the total 

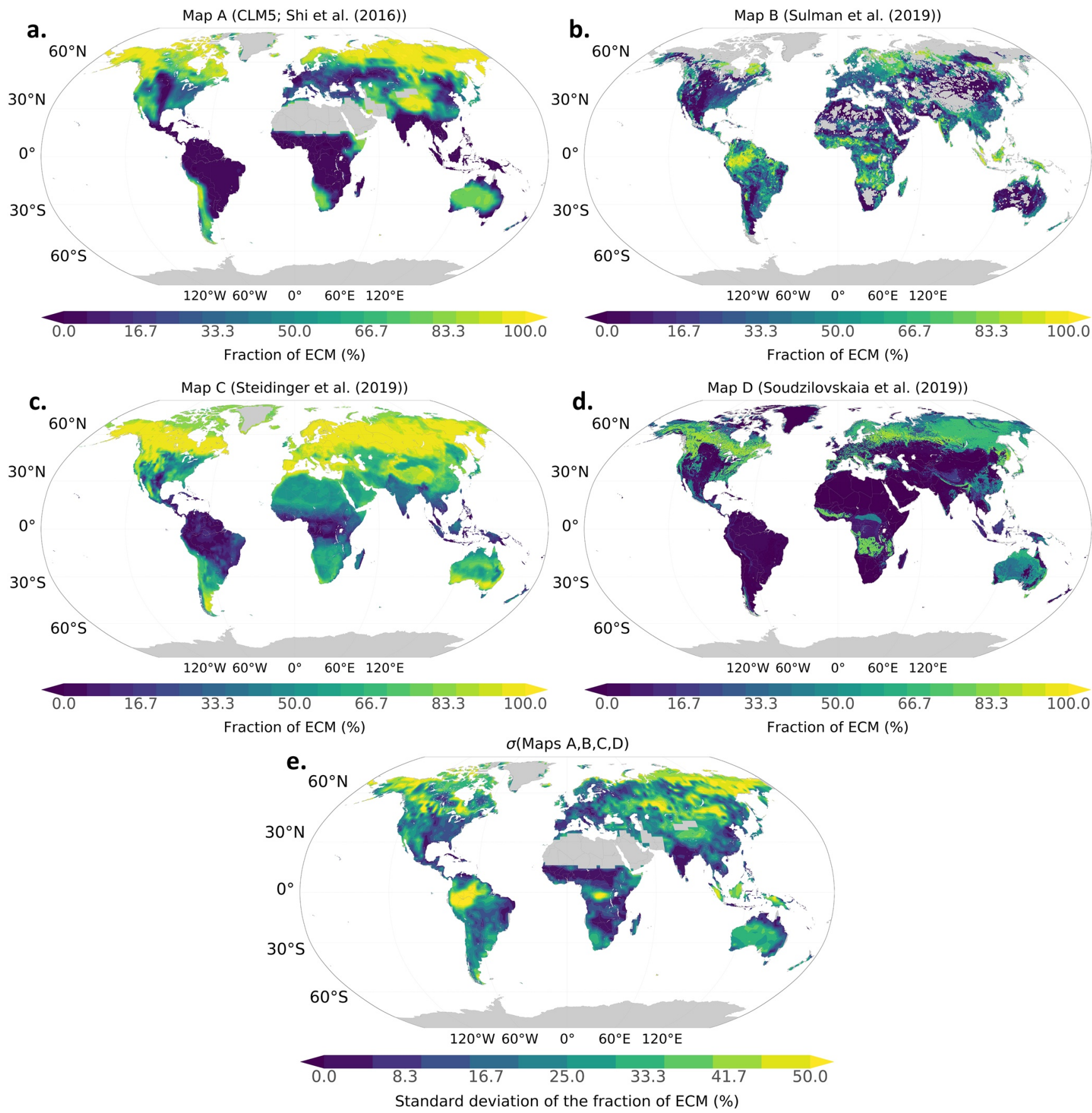

Figure 1. Different global spatial distributions of ectomycorrhizal fungi (ECM) fraction (\%). The remaining fraction is assumed to be AM. (a) Map A (Shi et al., 2016) (look-up table $\times$ PFTs in $\left.1.9 \times 2.5^{\circ}\right)$; (b) Map B (Sulman et al., 2019) $\left(0.17^{\circ} \times 0.17^{\circ}\right)$; (c) Map C (Steidinger et al., 2019$)\left(1.0 \times 1.0^{\circ}\right.$ unmasked); and (d) Map D (Soudzilovskaia et al., 2019) $\left(0.17 \times 0.17^{\circ}\right)$; and (e) Standard deviation of ECM fraction for all four maps. Gray areas represent no data. 
NPP for a particular grid cell, that area is not considered to be at risk of spending too much carbon on nitrogen acquisition. NL is calculated as:

$$
\mathrm{NL}(\text { lat, lon })=1 .-\frac{\propto_{1}(\text { lat, lon })}{\propto_{2}(\text { lat, lon })}
$$

where $\alpha_{1}$ is the slope of the linear regression of NPP used for Nitrogen uptake per gridcell (NPP_ NUPTAKE[lat,lon]) with time and $\alpha_{2}$ is the slope of the linear regression of NPP (NPP[lat,lon]) plus NPP NUPTAKE(lat,lon) with time.

\section{Results and Discussion}

\subsection{Different Estimates of Plant Symbiotic Status and Impacts on Nitrogen Uptake Pathways}

To better visualize the differences from maps presented in Figure 1, the standard deviation of the average ECM fraction (\%) across all four maps is shown in Figure 1e. A detailed description of each map can be found in the Supporting Information S1. Although all four maps agree in approximately $60 \%$ of the world area, some areas present large standard deviation values ( $>30 \%)$, for example, northern North America, northern and eastern Asia, as well as parts of tropical forests, that is, northwest Amazon, the central part of the Congo Basin, and parts of the maritime continent. These areas would benefit from more measurements of mycorrhizal association and further analysis. Remote sensing capabilities for mycorrhizal detection and hyperspectral Earth System modeling show promise for refining these estimates further (Braghiere et al., 2021; Fisher et al., 2012; Sousa et al., 2021). Map A (the default map in CLM5) presents the closest spatial patterns to map C, indicating an alignment of the assumptions that climate variables are the main drivers of global biogeography of plant-fungi symbiosis and the proposition that fixed values of mycorrhizal associations can be, to an extent, prescribed following PFTs spatial distributions as in map A.

Maps B and D suggest that map A overestimates ECM fraction in boreal regions, as well as drier areas of the world, such as the Atacama, Namibian, Somalian, Mongolian, Sonoran, and Australian deserts. All four maps present an ECM fraction between $30 \%$ and $60 \%$ in the eastern USA, while the standard deviation among maps over the same area is between $20 \%$ and $25 \%$, significantly higher than the standard deviation present in African savannas and grasslands, India, and northeast Brazil $(<10 \%)$. Comparatively, Europe and southeast Asia also present a standard deviation of 20\%-25\% in ECM fraction, while map A shows a lower fraction of ECM in Europe (20\%-40\%), followed by map B (30\%-40\%), map D (20\%-70\%), and map C (>90\%). In southeast Asia, maps A, B, and D show an ECM fraction between $0 \%$ and $40 \%$, while map C indicates higher values (40\%-75\%). Given that map A is based on PFT values, the biases in particular PFTs are presented in Figure S1.

The ECM-associated (NECM) and AM-associated (NAM) vegetation nitrogen uptake fluxes were the most impacted biogeochemical variables when including spatially explicit mycorrhizal status in CLM5, though the other nitrogen uptake pathways and their associated carbon costs were also impacted. Table S2 shows the average carbon cost per unit of nitrogen $\left(\mathrm{gN} \mathrm{kgC}^{-1}\right)$ in the period $2000-2010$ for each different nitrogen uptake pathway as predicted by CLM5. On average for the period 2000-2010, the updated total carbon cost per unit of nitrogen globally according to maps B, C, and D increases $2.2 \%$ relative to the default map A in CLM5. The main areas where carbon costs of nitrogen uptake became higher are eastern North America, Europe, southeast Asia, and the tropics for mycorrhizal uptake (see Supporting Information S1). Changes in carbon costs of nitrogen acquisition via mycorrhizae uptake are $4.1 \%$ higher globally compared to map A because maps B, C, and D present higher fraction of ECM in the tropics and lower fraction of AM in the extra-tropics. While AM fungi act as scavengers for soil nutrients, generally occupying more fertile sites, ECM fungi can mobilize nitrogen from soil organic matter, favorable in sites with lower soil fertility, but also requiring greater carbon expenditure for nutrient acquisition (Chapman et al., 2006; Marschner \& Dell, 1994; Read \& Perez-Moreno, 2003). Under constant root biomass $\left(0.1 \mathrm{kgC} \mathrm{m}^{-2}\right)$, the ECM carbon cost of nitrogen uptake is two times higher than the AM carbon cost of nitrogen uptake. Under constant soil nitrogen $\left(0.025 \mathrm{kgN} \mathrm{m}^{-2}\right)$, nitrogen uptake efficiency switches from AM to ECM as fine root biomass increases (Brzostek et al., 2014). Carbon costs devoted to each nitrogen uptake pathway individually are presented in Supporting Information S1. 
a.

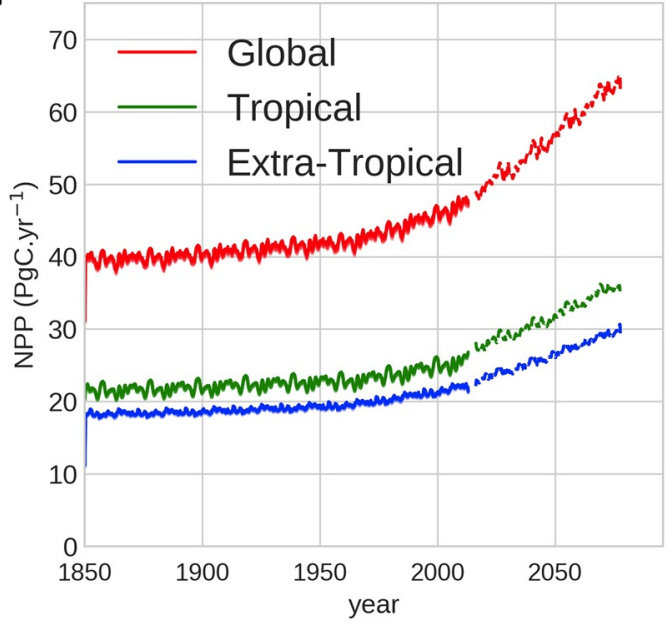

C.

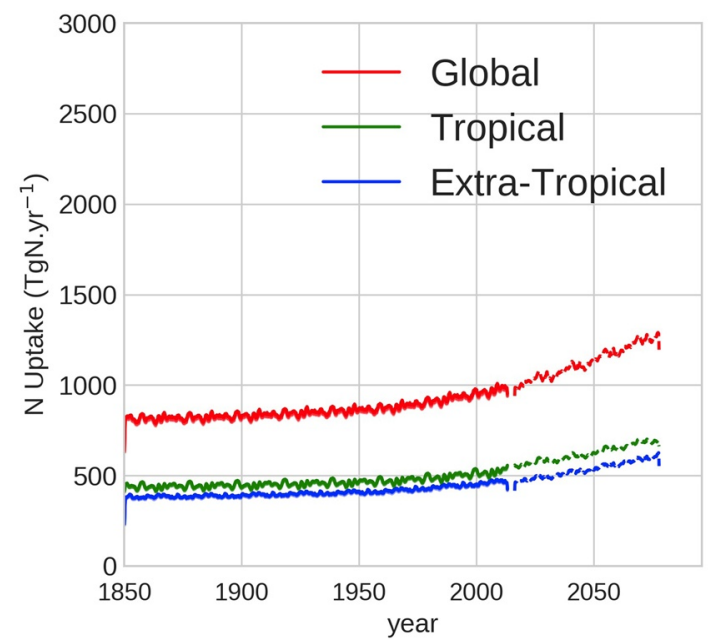

b.
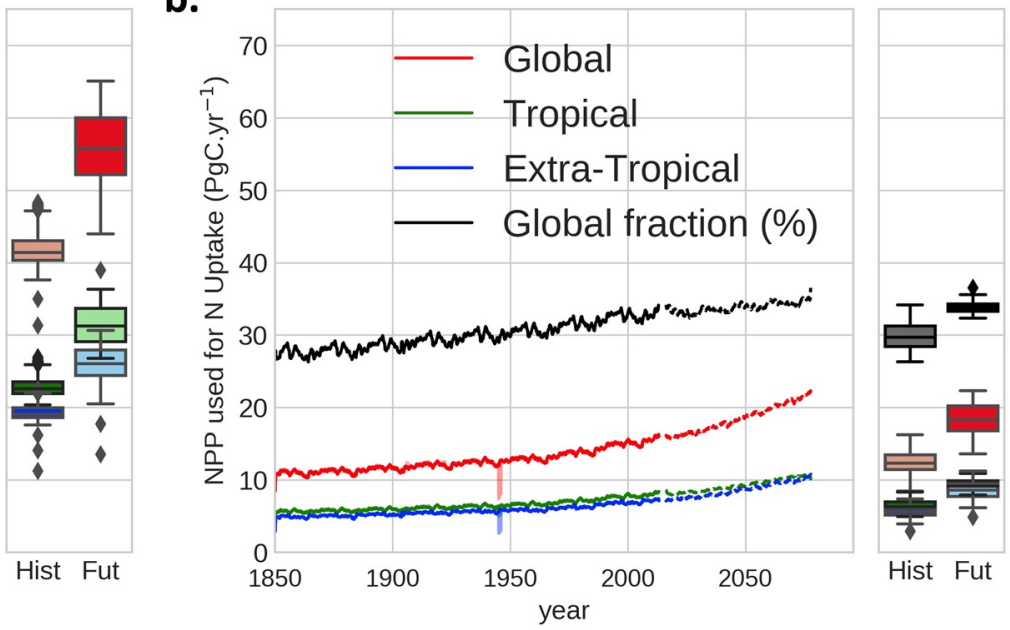

d.

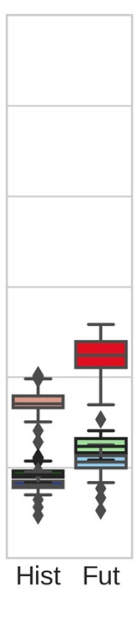

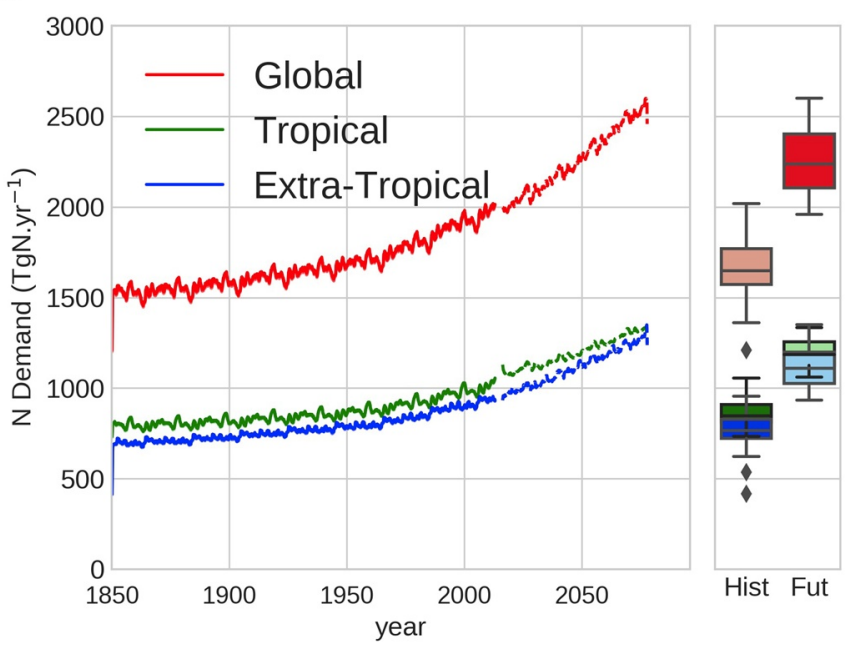

Figure 2. Trend in Net Primary Productivity (NPP) and its use for plant nitrogen acquisition (N Uptake) (a) Total NPP (PgC yr $\left.{ }^{-1}\right)$; (b) Total carbon cost of

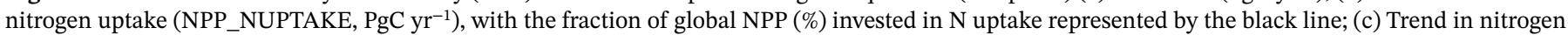
uptake and demand (c) Average nitrogen uptake (NUPTAKE, TgN yr ${ }^{-1}$ ); and (d) Average plant nitrogen demand (PLANT_NDEMAND, TgN yr ${ }^{-1}$ ) for the transient historical run from 1850 to 2010 (continuous) and for the future projection SSP5 with RCP8.5 run from 2015 to 2070 (dashed) with CLM5. Tropical is between $23.5^{\circ} \mathrm{S}$ and $23.5^{\circ} \mathrm{N}$. Extra-Tropical is the remaining area of the globe $\left(90^{\circ} \mathrm{S}-23.5^{\circ} \mathrm{S}\right.$ and $\left.23.5^{\circ} \mathrm{N}-90^{\circ} \mathrm{N}\right)$. Boxplots on the righthand show the historical (Hist) and future (Fut) distributions.

Previous versions of CLM without the FUN model do not have mycorrhizal representations. However, previous versions of CLM are substantially different from the current one, which would not allow for a straightforward comparison of emergent biogeochemical cycling patterns. Nevertheless, Shi et al. (2016) presented a detailed studied comparing the global carbon costs of nitrogen acquisition through each uptake pathway and Fisher et al. (2019) provided an evaluation of FUN parametric dependence in the CLM5.

\subsection{The Effect of Climate Change and $\mathrm{eCO}_{2}$ on Nitrogen Limitation}

Using the average of all four maps to determine the effect of climate change on NL, Figure 2 shows global

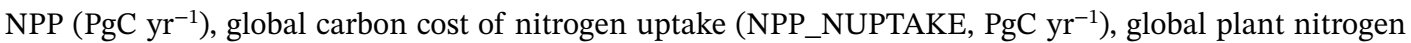
demand (PLANT_NDEMAND, $\mathrm{TgN} \mathrm{yr}^{-1}$ ), and the global nitrogen uptake (NUPTAKE, $\mathrm{TgN}^{-1} \mathrm{r}^{-1}$ ). Nitrogen demand is calculated as the total nitrogen that would be required if all assimilated carbon was allocated according to idealized stoichiometric ratios. The $\mathrm{CO}_{2}$ fertilization effect, with nitrogen deposition, and climate change increased photosynthetic rates across the globe, represented by an increase in NPP by $20 \%$ (40 


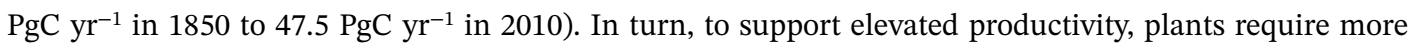
nitrogen, leading to an increase in plant nitrogen demand by $25 \%$ (from $\sim 1,600 \mathrm{TgN}^{-1}$ in 1850 to 2000

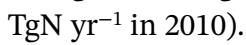

Although the rates of nitrogen uptake systematically increase in response to a higher nitrogen demand

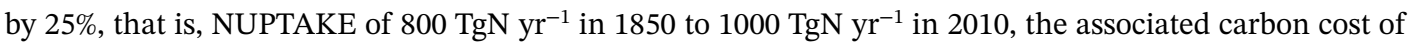
nitrogen acquisition increased at a faster rate, growing roughly $60 \%$ more expensive in $2010\left(17.5{\left.\mathrm{PgC} \mathrm{yr}^{-1}\right)}^{-1}\right.$ than it was in $1850\left(11.2 \mathrm{PgC} \mathrm{yr}^{-1}\right)$. In terms of the percentage of NPP spent in nitrogen acquisition, the values increased from $28 \%$ of NPP in 1850 to $33 \%$ of NPP in 2010. By 2075, it is projected that the NPP used

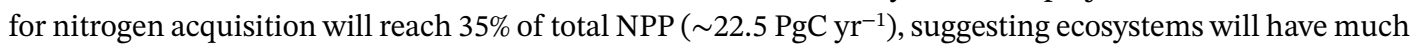
less carbon available for allocation and plant growth, possibly becoming more susceptible to extreme events that require extra carbon for re-growth, such as droughts, fires, and insect outbreaks.

All transient runs from 1850 to 2010 with the new maps (B, C, and D) indicated a stronger effect of climate and $\mathrm{eCO}_{2}$ on nitrogen limitation compared to map A. These findings highlight that as estimated by CLM5, not only has plant demand for nitrogen increased at a faster rate than actual nitrogen uptake, but also that the carbon costs associated with nitrogen acquisition have increased at a faster rate than the extra carbon gained through the $\mathrm{CO}_{2}$ fertilization effect, that is, plants need to invest more carbon per unit of nitrogen uptaken. This pattern is projected to continue in the future, which means that it is unlikely current plant growth rates will be sustained globally. Figure 3a shows the risk of nitrogen limitation (NL) calculated as described in Equation 3. According to the transient runs from 1850 to 2010 using the default mycorrhizal map in CLM5 (map A), tropical forests have a medium to low risk of being further limited by nitrogen, which is in agreement with studies indicating that intact ancient tropical forests tend to accumulate and recycle large quantities of nitrogen relative to temperate forests (Hedin et al., 2009).

Savannas and forest-grassland transition zones in South America, Africa, and Australia, present a higher risk of NL to plant growth. Parts of the temperate forests in North America, Europe, and Asia, as well as boreal forests present a medium to high risk of nitrogen limitation.

\subsection{The Feedback Impacts of Mycorrhizal Changes Due to Climate Change}

Recent evidence suggests that anthropogenic influences, primarily nitrogen deposition and fire suppression, as well as climate change have increased AM dominance during the past three decades in the eastern United States (Jo et al., 2019). Globally, Steidinger et al. (2019) presented a study using the same environment-mycorrhizae relationships for current climate to project potential changes in the symbiotic status of forests in the future, suggesting that projected climate for 2070 will reduce the abundance of ECM trees by as much as $10 \%$, with major changes in ECM abundance along the boreal-temperate transition zone (Figure 3b).

Although the magnitude of the time lag between climate change and ecosystem responses is unknown, the predicted decline in ECM trees aligns with previous simulated warming experiments, which have demonstrated that some important ECM hosts decline at the boreal-temperate zones under future climate conditions (Reich et al., 2015). ECM fungi demonstrated increased responses of mycorrhizal fungal biomass under $\mathrm{eCO}_{2}$ compared to AM fungi (Dong et al., 2018), as the simulated response in the tropics (Figure 3b).

While it has been previously reported that climate change should impact forest symbiosis, no study has ever evaluated the potential feedback of climate change effects on mycorrhizal distribution onto carbon and nitrogen cycles. The difference in NPP for the period of 2016-2075 between the simulations using the future maps of ECM fraction and the simulations using the present-day map C (Steidinger et al., 2019) are shown in Figure 3c.

Large parts of South America, especially areas associated with savannas, present the largest negative feedback effects on NPP due to future climate change impacts on mycorrhizal association, followed by areas with boreal forests. The impact over tropical forests and areas in China seems to benefit from a change in plant symbiotic status in the future. Although, these results should be interpreted carefully due to the limitation of the original forest plot training data in those areas of the globe used in Steidinger et al. (2019), 


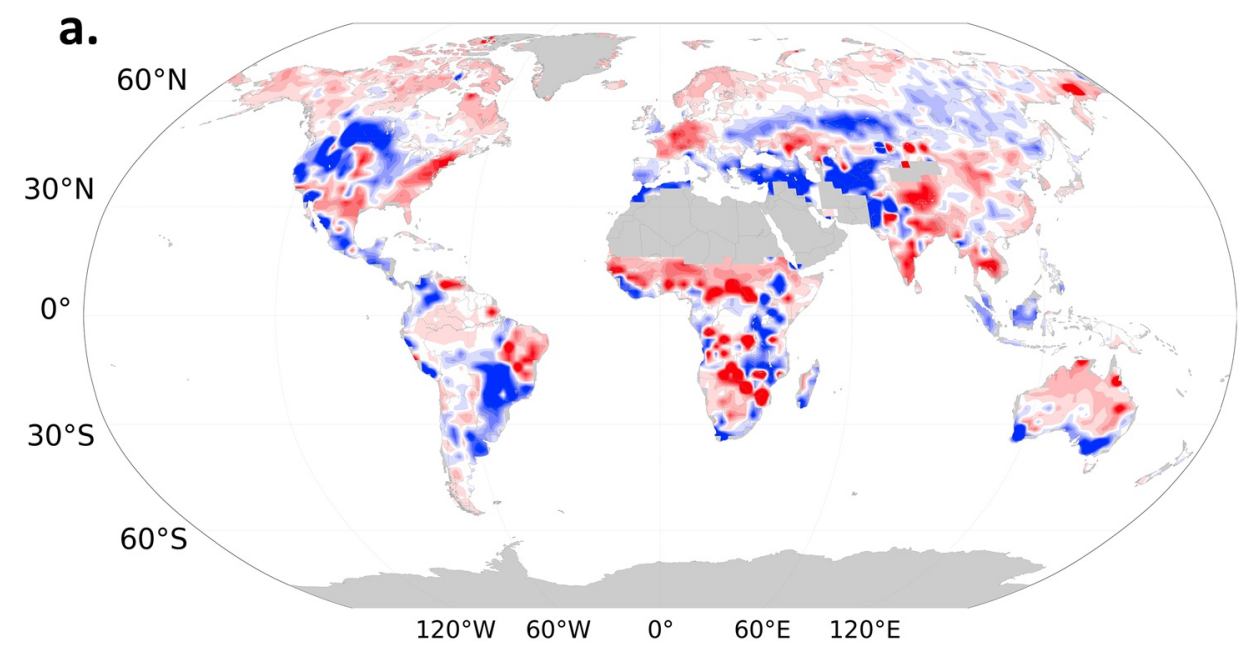

Low risk

Medium risk

High risk
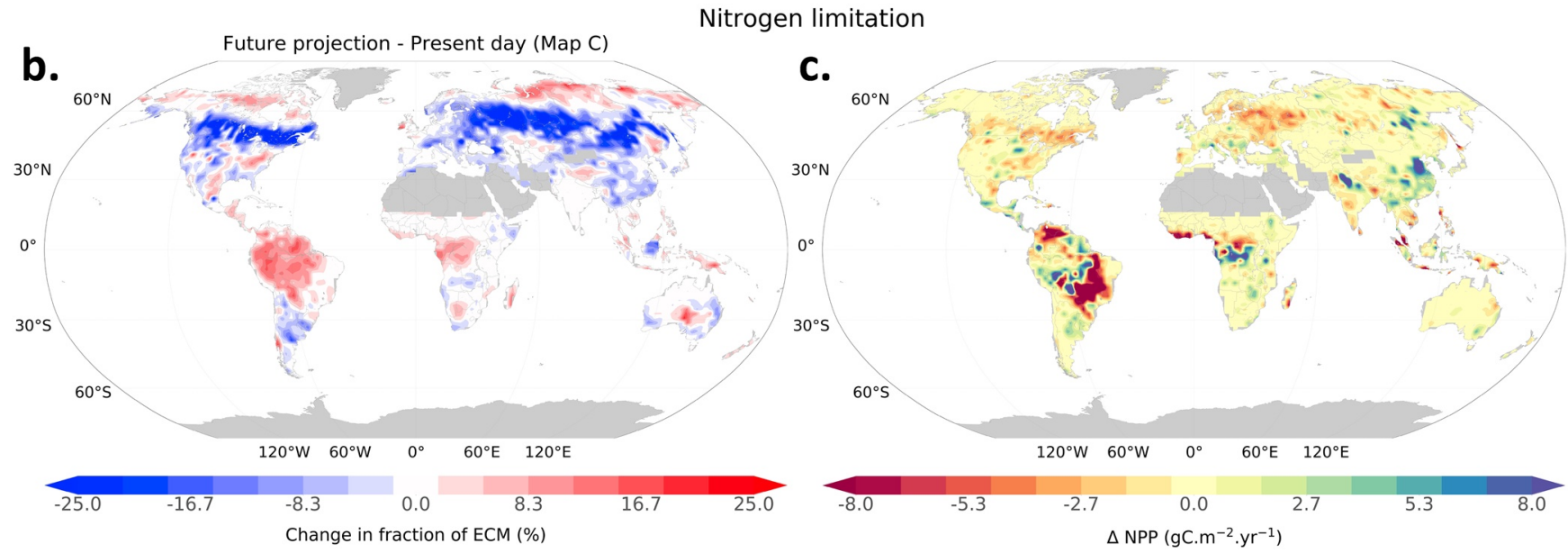

Figure 3. (a) Risk of nitrogen limitation. Areas in red indicate higher risk of nitrogen limitation for NPP, and areas in blue indicate lower risk of nitrogen limitation for NPP; (b) The impact of climate change on ECM fraction (\%) derived from Steidinger et al. (2019) for 2070 following the RCP8.5 with CMIP5 simulations; (c) Difference in NPP $\left(\mathrm{gC} \mathrm{m}^{-2} \mathrm{yr}^{-1}\right)$ for future simulations (2016-2075) between projected future map generated for the year of 2070 and the present-day map C (Steidinger et al., 2019). The projected runs with CLM5 followed the SSP5 scenario in combination with RCP8.5 climate forcing from CESM2, member of CMIP6 simulations.

machine learning algorithms indicate more ECM fungi in the tropics in the future, possibly due to the $\mathrm{eCO}_{2}$ effect on the tropical climate.

In the SSP5-RCP8.5 runs from 2016 to 2075 with present-day plant symbiotic status, the growth rate of nitrogen uptake was $4.8 \mathrm{TgN} \mathrm{yr}^{-2}$. In terms of carbon costs, NPP is projected to increase at a rate of $265.5 \mathrm{TgC} \mathrm{yr}^{-2}$, while the carbon cost of nitrogen acquisition is projected to increase at a rate of $130.4 \mathrm{TgC}^{-2}$. The feedback effect of climate change on the spatial distribution of plant symbiotic status decreases NPP globally

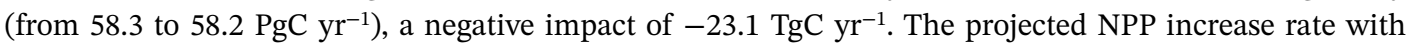

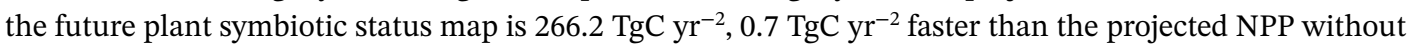
changes in mycorrhizae associations. However, the carbon cost of nitrogen acquisition is projected to increase at a rate of $129.1 \mathrm{TgC} \mathrm{yr}^{-2}$, versus $130.0 \mathrm{TgC} \mathrm{yr}^{-2}$ in the simulations without changes in the spatial distribution of plant symbiotic status. In terms of global NPP, these changes are predicted to increase carbon costs of nitrogen acquisition by $582.5 \mathrm{TgC}_{\mathrm{gr}} \mathrm{r}^{-1}$, which significantly amplifies the effect of nutrient limitation on plant growth worldwide. 


\section{Conclusions}

To overcome the lack of global spatial representations of mycorrhizal associations, recent studies have assembled high-resolution digital maps of the global distribution of biomass fractions of different types of mycorrhizae associations.

In our analysis, we show that differences between these data products have significant impacts on the nitrogen and carbon cycles in CLM5. Nonetheless, this comparison did not aim to determine which map is the most accurate. Rather, we assessed the impact of different mycorrhizal representations in CLM5 to determine signs of changes in the global nitrogen and carbon cycles. We found a negative impact on future NPP due to feedback effects of climate change and $\mathrm{eCO}_{2}$ on mycorrhizae spatial distribution.

Although the model runs with different spatial representations of plant symbiotic status differ substantially in terms of total nitrogen acquisition and their relative carbon costs, all experiments using the observation based maps do agree that the increasing rate of plant nitrogen demand is higher than the rate of nitrogen uptake as previously reported. Moreover, our simulations found that the carbon costs of nitrogen acquisition also increase at a higher rate than NPP itself, indicating that plants must invest more carbon per unit of nitrogen uptake to sustain growth at current rates globally.

This is the first study using multiple observation-derived global maps of mycorrhizal association within an ESM to estimate the impacts of climate change on mycorrhizae and their feedback on global carbon and nitrogen cycles. Future model developments include better constraining cost parameter functions with model-observation fusion frameworks, as well as the addition of other nutrients and mycorrhizal types (such as ericoid mycorrhizae).

\section{Data Availability Statement}

A patch file with the modified version of CLM5 and all python scripts used for analyses and plots are available in https://doi.org/10.6084/m9.figshare.12919385.v1.

\section{Acknowledgments}

This research was carried out at the Jet Propulsion Laboratory, California Institute of Technology, under a contract with the National Aeronautics and Space Administration. California Institute of Technology. Government sponsorship acknowledged. This material is based upon work supported by the U.S. Department of Energy, Office of Science, Office of Biological and Environmental Research, Terrestrial Ecosystem Science program under Award Numbers DE-SC0008317 and DE-SC0016188. Funding was also provided by the NASA IDS program. Copyright 2021. All rights reserved. MS was partly supported by the U.S. Department of Energy Office of Science Biological and Environmental Research as part of the Terrestrial Ecosystem Science Program through the Next-Generation Ecosystem Experiments (NGEE) Tropics project. PNNL is operated by Battelle Memorial Institute for the U.S. DOE under contract DE-AC0576RLO1830. We would like to acknowledge high-performance computing support from Cheyenne (NCAR, 2020) provided by NCAR's Computational and Information Systems Laboratory, sponsored by the National Science Foundation.

\section{References}

Allen, K., Fisher, J. B., Phillips, R. P., Powers, J. S., \& Brzostek, E. R. (2020). Modeling the carbon cost of plant nitrogen and phosphorus uptake across temperate and tropical forests. Frontiers in Forests and Global Change, 3. https://doi.org/10.3389/ffgc.2020.00043

Braghiere, R. K., Quaife, T., Black, E., He, L., \& Chen, J. M. (2019). Underestimation of global photosynthesis in Earth system models due to representation of vegetation structure. Global Biogeochemical Cycles, 33(11), 1358-1369. https://doi.org/10.1029/2018GB006135

Braghiere, R. K., Wang, Y., Doughty, R., Sousa, D., Magney, T., Widlowski, J.-L., et al. (2021). Accounting for canopy structure improves hyperspectral radiative transfer and sun-induced chlorophyll fluorescence representations in a new generation Earth System model. Remote Sensing of Environment, 261, 112497. https://doi.org/10.1016/j.rse.2021.112497

Brundrett, M. C. (2017). Distribution and evolution of mycorrhizal types and other specialised roots in Australia (pp. 361-394). Springer. https://doi.org/10.1007/978-3-319-56363-3_17

Brzostek, E. R., Fisher, J. B., \& Phillips, R. P. (2014). Modeling the carbon cost of plant nitrogen acquisition: Mycorrhizal trade-offs and multipath resistance uptake improve predictions of retranslocation. Journal of Geophysical Research: Biogeosciences, 119(8), $1684-1697$. https://doi.org/10.1002/2014JG002660

Chapman, S. K., Langley, J. A., Hart, S. C., \& Koch, G. W. (2006). Plants actively control nitrogen cycling: Uncorking the microbial bottleneck. New Phytologist, 169(1), 27-34. https://doi.org/10.1111/J.1469-8137.2005.01571.X

Chen, C., Park, T., Wang, X., Piao, S., Xu, B., Chaturvedi, R. K., et al. (2019). China and India lead in greening of the world through land-use management. Nature Sustainability, 2(2), 122-129. https://doi.org/10.1038/s41893-019-0220-7

Ciais, P., Sabine, C., Bala, G., Bopp, L., Brovkin, V., Canadell, J., et al. (2013). Carbon and other biogeochemical cycles. In T. F. Stocker, D. Qin, G.-K. Plattner, M. Tignor, S. K. Allen, J. Boschung, et al. (Eds.), Climate change 2013-The physical science basis (pp. 465-570). Cambridge University Press.

Davies-Barnard, T., Meyerholt, J., Zaehle, S., Friedlingstein, P., Brovkin, V., Fan, Y., et al. (2020). Nitrogen cycling in CMIP6 land surface models: Progress and limitations. Biogeosciences, 17, 5129-5148. https://doi.org/10.5194/bg-17-5129-2020

Dong, Y., Wang, Z., Sun, H., Yang, W., \& Xu, H. (2018). The response patterns of Arbuscular Mycorrhizal and Ectomycorrhizal Symbionts under elevated $\mathrm{CO}_{2}$ : A meta-analysis. Frontiers in Microbiology, 9. https://doi.org/10.3389/fmicb.2018.01248

Drake, J. E., Gallet-Budynek, A., Hofmockel, K. S., Bernhardt, E. S., Billings, S. A., Jackson, R. B., et al. (2011). Increases in the flux of carbon belowground stimulate nitrogen uptake and sustain the long-term enhancement of forest productivity under elevated $\mathrm{CO}_{2}$. Ecology Letters, 14(4), 349-357. https://doi.org/10.1111/j.1461-0248.2011.01593.x

Eyring, V., Bony, S., Meehl, G. A., Senior, C. A., Stevens, B., Stouffer, R. J., \& Taylor, K. E. (2016). Overview of the Coupled Model Intercomparison Project Phase 6 (CMIP6) experimental design and organization. Geoscientific Model Development, 9(5), 1937-1958. https:// doi.org/10.5194/gmd-9-1937-2016

Fisher, J. B., Badgley, G., \& Blyth, E. (2012). Global nutrient limitation in terrestrial vegetation. Global Biogeochemical Cycles, 26(3), 2011GB004252. https://doi.org/10.1029/2011GB004252 
Fisher, J. B., Sitch, S., Malhi, Y., Fisher, R. A., Huntingford, C., \& Tan, S.-Y. (2010). Carbon cost of plant nitrogen acquisition: A mechanistic, globally applicable model of plant nitrogen uptake, retranslocation, and fixation. Global Biogeochemical Cycles, 24(1). https://doi. org/10.1029/2009GB003621

Fisher, R. A., Wieder, W. R., Sanderson, B. M., Koven, C. D., Oleson, K. W., Xu, C., et al. (2019). Parametric controls on vegetation responses to biogeochemical forcing in the CLM5. Journal of Advances in Modeling Earth Systems, 11(9), 2879-2895. https://doi. org/10.1029/2019MS001609

Fleischer, K., Rammig, A., De Kauwe, M. G., Walker, A. P., Domingues, T. F., Fuchslueger, L., et al. (2019). Amazon forest response to CO fertilization dependent on plant phosphorus acquisition. Nature Geoscience, 12(9), 736-741. https://doi.org/10.1038/s41561-019-0404-9

Friedlingstein, P., Cox, P., Betts, R., Bopp, L., von Bloh, W., Brovkin, V., et al. (2006). Climate-carbon cycle feedback analysis: Results from the C4MIP model intercomparison. Journal of Climate, 19, 3337-3353. https://doi.org/10.1175/JCLI3800.1

Friedlingstein, P., Meinshausen, M., Arora, V. K., Jones, C. D., Anav, A., Liddicoat, S. K., \& Knutti, R. (2014). Uncertainties in CMIP5 climate projections due to carbon cycle feedbacks. Journal of Climate, 27(2), 511-526. https://doi.org/10.1175/JCLI-D-12-00579.1

Friedlingstein, P., O'Sullivan, M., Jones, M. W., Andrew, R. M., Hauck, J., Olsen, A., et al. (2020). Global carbon budget 2020 . Earth System Science Data, 12(4), 3269-3340. https://doi.org/10.5194/essd-12-3269-2020

Goll, D. S., Winkler, A. J., Raddatz, T., Dong, N., Prentice, I. C., Ciais, P., \& Brovkin, V. (2017). Carbon-nitrogen interactions in idealized simulations with JSBACH (version 3.10). Geoscientific Model Development, 10(5), 2009-2030. https://doi.org/10.5194/gmd-10-2009-2017

Hedin, L. O., Brookshire, E. N. J., Menge, D. N. L., \& Barron, A. R. (2009). The nitrogen paradox in tropical forest ecosystems. Annual Review of Ecology, Evolution, and Systematics, 40(1), 613-635. https://doi.org/10.1146/annurev.ecolsys.37.091305.110246

Jo, I., Fei, S., Oswalt, C. M., Domke, G. M., \& Phillips, R. P. (2019). Shifts in dominant tree mycorrhizal associations in response to anthropogenic impacts. Science Advances, 5(4), eaav6358. https://doi.org/10.1126/sciadv.aav6358

Keenan, T. F., Prentice, I. C., Canadell, J. G., Williams, C., Wang, H., Raupach, M. R., \& Collatz, G. J. (2016). Recent pause in the growth rate of atmospheric $\mathrm{CO}_{2}$ due to enhanced terrestrial carbon uptake. Nature Communications, 7. https://doi.org/10.1038/ncomms13428

Kim, H. (2017). Global soil wetness project phase 3 atmospheric boundary conditions (experiment 1). Data Integration and Analysis System (DIAS). https://doi.org/10.20783/DIAS.501

Kivlin, S. N., Emery, S. M., \& Rudgers, J. A. (2013). Fungal symbionts alter plant responses to global change. American Journal of Botany, 100(7), 1445-1457. https://doi.org/10.3732/ajb.1200558

Kolus, H. R., Huntzinger, D. N., Schwalm, C. R., Fisher, J. B., McKay, N., Fang, Y., et al. (2019). Land carbon models underestimate the severity and duration of drought's impact on plant productivity. Scientific Reports, 9(1), 2758. https://doi.org/10.1038/s41598-019-39373-1

Kriegler, E., Bauer, N., Popp, A., Humpenöder, F., Leimbach, M., Strefler, J., et al. (2017). Fossil-fueled development (SSP5): An energy and resource intensive scenario for the 21st century. Global Environmental Change, 42, 297-315. https://doi.org/10.1016/j. gloenvcha.2016.05.015

Lawrence, D. M., Fisher, R. A., Koven, C. D., Oleson, K. W., Swenson, S. C., Bonan, G., et al. (2019). The community land model version 5: Description of new features, benchmarking, and impact of forcing uncertainty. Journal of Advances in Modeling Earth Systems, 11(12), 4245-4287. https://doi.org/10.1029/2018MS001583

Lawrence, D. M., Hurtt, G. C., Arneth, A., Brovkin, V., Calvin, K. V., Jones, A. D., et al. (2016). The land use model intercomparison project (LUMIP) contribution to CMIP6: Rationale and experimental design. Geoscientific Model Development, 9(9), 2973-2998. https://doi. org/10.5194/gmd-9-2973-2016

Marschner, H., \& Dell, B. (1994). Nutrient uptake in mycorrhizal symbiosis. Plant and Soil, 159(1), 89-102. https://doi.org/10.1007/ BF00000098

Menzel, A., Hempel, S., Manceur, A. M., Götzenberger, L., Moora, M., Rillig, M. C., et al. (2016). Distribution patterns of arbuscular mycorrhizal and non-mycorrhizal plant species in Germany. Perspectives in Plant Ecology, Evolution and Systematics, 21, 78-88. https://doi. org/10.1016/j.ppees.2016.06.002

NCAR. (2020). Cheyenne. https://doi.org/10.5065/D6RX99HX

Norby, R. J., De Kauwe, M. G., Walker, A. P., Werner, C., Zaehle, S., \& Zak, D. R. (2017). Comment on "Mycorrhizal association as a primary control of the $\mathrm{CO}_{2}$ fertilization effect. Science, 355(6323), 2-358. 358. https://doi.org/10.1126/science.aai7976

O'Neill, B. C., Tebaldi, C., Van Vuuren, D. P., Eyring, V., Friedlingstein, P., Hurtt, G., et al. (2016). The scenario model intercomparison project (ScenarioMIP) for CMIP6. Geoscientific Model Development, 9(9), 3461-3482. https://doi.org/10.5194/gmd-9-3461-2016

Orwin, K. H., Kirschbaum, M. U. F., St John, M. G., \& Dickie, I. A. (2011). Organic nutrient uptake by mycorrhizal fungi enhances ecosystem carbon storage: A model-based assessment. Ecology Letters, 14(5), 493-502. https://doi.org/10.1111/j.1461-0248.2011.01611.x

Read, D. J., \& Perez-Moreno, J. (2003). Mycorrhizas and nutrient cycling in ecosystems-A journey towards relevance? New Phytologist, 157(3), 475-492. https://doi.org/10.1046/j.1469-8137.2003.00704.x

Reich, P. B., Sendall, K. M., Rice, K., Rich, R. L., Stefanski, A., Hobbie, S. E., \& Montgomery, R. A. (2015). Geographic range predicts photosynthetic and growth response to warming in co-occurring tree species. Nature Climate Change, 5(2), 148-152. https://doi.org/10.1038/ nclimate 2497

Schimel, D., Stephens, B. B., \& Fisher, J. B. (2015). Effect of increasing $\mathrm{CO}_{2}$ on the terrestrial carbon cycle. Proceedings of the National Academy of Sciences, 112(2), 436-441. https://doi.org/10.1073/pnas.1407302112

Shi, M., Fisher, J. B., Brzostek, E. R., \& Phillips, R. P. (2016). Carbon cost of plant nitrogen acquisition: Global carbon cycle impact from an improved plant nitrogen cycle in the Community Land Model. Global Change Biology, 22(3), 1299-1314. https://doi.org/10.1111/ gcb.13131

Soudzilovskaia, N. A., van Bodegom, P. M., Terrer, C., Zelfde, M. V. Z., McCallum, I., Luke McCormack, M., et al. (2019). Global mycorrhizal plant distribution linked to terrestrial carbon stocks. Nature Communications, 10(1), 5077. https://doi.org/10.1038/s41467-019-13019-2

Sousa, D., Fisher, J. B., Galvan, F. R., Pavlick, R. P., Cordell, S., Giambelluca, T. W., et al. (2021). Tree canopies reflect Mycorrhizal composition. Geophysical Research Letters, 48(10), e2021GL092764. https://doi.org/10.1029/2021GL092764

Steidinger, B. S., Crowther, T. W., Liang, J., Van Nuland, M. E., Werner, G. D. A., Reich, P. B., et al. (2019). Climatic controls of decomposition drive the global biogeography of forest-tree symbioses. Nature, 569(7756), 404-408. https://doi.org/10.1038/s41586-019-1128-0

Sulman, B. N., Brzostek, E. R., Medici, C., Shevliakova, E., Menge, D. N. L., \& Phillips, R. P. (2017). Feedbacks between plant N demand and rhizosphere priming depend on type of mycorrhizal association. Ecology Letters, 20(8), 1043-1053. https://doi.org/10.1111/ele.12802

Sulman, B. N., Shevliakova, E., Brzostek, E. R., Kivlin, S. N., Malyshev, S., Menge, D. N. L., \& Zhang, X. (2019). Diverse Mycorrhizal associations enhance terrestrial C storage in a global model. Global Biogeochemical Cycles, 33(4), 501-523. https://doi.org/10.1029/2018GB005973

Swaty, R., Michael, H. M., Deckert, R., \& Gehring, C. A. (2016). Mapping the potential mycorrhizal associations of the conterminous United States of America. Fungal Ecology, 24, 139-147. https://doi.org/10.1016/j.funeco.2016.05.005 
Terrer, C., Jackson, R. B., Prentice, I. C., Keenan, T. F., Kaiser, C., Vicca, S., et al. (2019). Nitrogen and phosphorus constrain the $\mathrm{CO}_{2}$ fertilization of global plant biomass. Nature Climate Change, 9(9), 684-689. https://doi.org/10.1038/s41558-019-0545-2

Terrer, C., Phillips, R. P., Hungate, B. A., Rosende, J., Pett-Ridge, J., Craig, M. E., et al. (2021). A trade-off between plant and soil carbon storage under elevated $\mathrm{CO}_{2}$. Nature, 591(7851), 599-603. https://doi.org/10.1038/s41586-021-03306-8

Terrer, C., Vicca, S., Hungate, B. A., Phillips, R. P., \& Prentice, I. C. (2016). Mycorrhizal association as a primary control of the $\mathrm{CO}_{2}$ fertilization effect. Science, 353(6294), 72-74. https://doi.org/10.1126/science.aaf4610

Terrer, C., Vicca, S., Stocker, B. D., Hungate, B. A., Phillips, R. P., Reich, P. B., et al. (2018). Ecosystem responses to elevated $\mathrm{CO}_{2}$ governed by plant-soil interactions and the cost of nitrogen acquisition. New Phytologist, 217(2), 507-522. https://doi.org/10.1111/nph.14872

Trenberth, K. E., Dai, A., van der Schrier, G., Jones, P. D., Barichivich, J., Briffa, K. R., \& Sheffield, J. (2014). Global warming and changes in drought. Nature Climate Change, 4(1), 17-22. https://doi.org/10.1038/nclimate2067

van der Heijden, M. G. A., Martin, F. M., Selosse, M.-A., \& Sanders, I. R. (2015). Mycorrhizal ecology and evolution: The past, the present, and the future. New Phytologist, 205(4), 1406-1423. https://doi.org/10.1111/nph.13288

Walker, A. P., De Kauwe, M. G., Bastos, A., Belmecheri, S., Georgiou, K., Keeling, R. F., et al. (2021). Integrating the evidence for a terrestrial carbon sink caused by increasing atmospheric $\mathrm{CO}_{2}$. New Phytologist, 229(5), 2413-2445. https://doi.org/10.1111/NPH.16866

Wang, Y. P., Law, R. M., \& Pak, B. (2010). A global model of carbon, nitrogen and phosphorus cycles for the terrestrial biosphere. Biogeosciences, 7(7), 2261-2282. https://doi.org/10.5194/bg-7-2261-2010

Wieder, W. R., Cleveland, C. C., Smith, W. K., \& Todd-Brown, K. (2015). Future productivity and carbon storage limited by terrestrial nutrient availability. Nature Geoscience, 8(6), 441-444. https://doi.org/10.1038/ngeo2413

Wieder, W. R., Lawrence, D. M., Fisher, R. A., Bonan, G. B., Cheng, S. J., Goodale, C. L., et al. (2019). Beyond static benchmarking: Using experimental manipulations to evaluate land model assumptions. Global Biogeochemical Cycles, 33, 1289-1309. https://doi. org/10.1029/2018GB006141

Zaehle, S., Friedlingstein, P., \& Friend, A. D. (2010). Terrestrial nitrogen feedbacks may accelerate future climate change. Geophysical Research Letters, 37(1). https://doi.org/10.1029/2009GL041345

Zaehle, S., Jones, C. D., Houlton, B., Lamarque, J.-F., \& Robertson, E. (2015). Nitrogen availability reduces CMIP5 projections of twenty-first-century land carbon uptake. Journal of Climate, 28(6), 2494-2511. https://doi.org/10.1175/JCLI-D-13-00776.1

Zhang, Y., Song, C., Band, L. E., \& Sun, G. (2019). No proportional increase of terrestrial gross carbon sequestration from the greening Earth. Journal of Geophysical Research: Biogeosciences, 124, 2540-2553. https://doi.org/10.1029/2018JG004917

Zhu, Z., Piao, S., Myneni, R. B., Huang, M., Zeng, Z., Canadell, J. G., et al. (2016). Greening of the Earth and its drivers. Nature Climate Change, 6, 791-795. https://doi.org/10.1038/NCLIMATE3004

\section{References From the Supporting Information}

Ali, A. A., Xu, C., Rogers, A., Fisher, R. A., Wullschleger, S. D., Massoud, E. C., et al. (2016). A global scale mechanistic model of photosynthetic capacity (LUNA V1.0). Geoscientific Model Development, 9(2), 587-606. https://doi.org/10.5194/gmd-9-587-2016

Allen, E. B., Allen, M. F., Helm, D. J., Trappe, J. M., Molina, R., \& Rincon, E. (1995). Patterns and regulation of mycorrhizal plant and fungal diversity. Plant and Soil, 170(1), 47-62. https://doi.org/10.1007/BF02183054

Bailey, R. G. (2014). Ecoregions: The ecosystem geography of the oceans and continents. Ecoregions: The ecosystem geography of the oceans and continents. Springer. https://doi.org/10.1007/978-1-4939-0524-9

Bartholomé, E., \& Belward, A. S. (2005). GLC2000: A new approach to global land cover mapping from Earth observation data. International Journal of Remote Sensing, 26(9), 1959-1977. https://doi.org/10.1080/01431160412331291297

Cheng, S. J., Hess, P. G., Wieder, W. R., Thomas, R. Q., Nadelhoffer, K. J., Vira, J., et al. (2019). Decadal fates and impacts of nitrogen additions on temperate forest carbon storage: A data-model comparison. Biogeosciences, 16(13), 2771-2793. https://doi.org/10.5194/ bg-16-2771-2019

ESA. (2017). CCI Land cover map 2015.

Ghimire, B., Riley, W. J., Koven, C. D., Mu, M., \& Randerson, J. T. (2016). Representing leaf and root physiological traits in CLM improves global carbon and nitrogen cycling predictions. Journal of Advances in Modeling Earth Systems, 8, 598-613. https://doi. org/10.1002/2015MS000538

Kennedy, D., Swenson, S., Oleson, K. W., Lawrence, D. M., Fisher, R., Lola da Costa, A. C., \& Gentine, P. (2019). Implementing plant hydraulics in the Community Land Model, version 5. Journal of Advances in Modeling Earth Systems, 11(2), 485-513. https://doi. org/10.1029/2018MS001500

NCAR. (2019). CLM5 documentation release (p. 337)

Öpik, M., Vanatoa, A., Vanatoa, E., Moora, M., Davison, J., Kalwij, J. M., et al. (2010). The online database MaarjAM reveals global and ecosystemic distribution patterns in arbuscular mycorrhizal fungi (Glomeromycota). New Phytologist, 188(1), 223-241. https://doi. org $/ 10.1111 / \mathrm{j} .1469-8137.2010 .03334 . x$

Phillips, R. P., Brzostek, E., \& Midgley, M. G. (2013). The mycorrhizal-associated nutrient economy: A new framework for predicting carbon-nutrient couplings in temperate forests. New Phytologist, 199(1), 41-51. https://doi.org/10.1111/nph.12221

Read, D. J. (1991). Mycorrhizas in ecosystems. Experientia, 47(4), 376-391. https://doi.org/10.1007/BF01972080

Tedersoo, L., Bahram, M., Põlme, S., Kõljalg, U., Yorou, N. S., Wijesundera, R., et al. (2014). Global diversity and geography of soil fungi. Science, 346(6213), 1256688. https://doi.org/10.1126/science.1256688

Xu, C., Fisher, R., Wullschleger, S. D., Wilson, C. J., Cai, M., \& McDowell, N. G. (2012). Toward a mechanistic modeling of nitrogen limitation on vegetation dynamics. PloS One, 7(5), 1-11. https://doi.org/10.1371/journal.pone.0037914 